\title{
Media Stamp Game untuk Meningkatkan Kemampuan Berhitung Anak Slow Learner di Sekolah Dasar
}

\author{
Suci Wulandari, Susanti Prasetyaningrum \\ Universitas Muhammadiyah Malang, Jl. Bendungan Sutami No.188, Lowokwaru, Kota Malang \\ e-mail: suciwulandari1402@gmail.com
}

\begin{abstract}
Slow learner children may find it hard to learn abstract and symbolic concepts, which could lead to difficulties in math learning, such as sum. The stamp game is a learning media with a concept to teach count operation (sum) with concrete form that is easy to use by children with simple steps and used repeatedly to reinforce the concepts. Thus, it may improve math ability in slow learner children. The purpose of this study is to improve the ability of counting operations (sum) in elementary school students who are slow learner by using the stamp game. This study used single case experimental design. The participants were three slow learner children selected using purposive sampling technique. The results of the research show that the stamp game can improve counting (sum) ability in elementary school students who are a slow learner.
\end{abstract}

Keywords: stamp game media, the ability to counting, slow learner

\begin{abstract}
Abstrak
Anak slow learner terbatas dalam menangani konsep abstrak dan simbolis, sehingga mengalami kesulitan dalam berhitung salah satunya penjumlahan. The stamp game adalah media belajar yang memiliki konsep untuk mengajarkan operasi hitung penjumlahan dengan wujud konkret yang mudah digunakan oleh anak dengan langkah yang sederhana dan digunakan secara berulang untuk menguatkan konsep yang sedang dipelajari, sehingga media ini dapat meningkatkan kemampuan berhitung (penjumlahan) pada anak slow learner. Tujuan penelitian ini adalah untuk meningkatkan kemampuan operasi hitung (penjumlahan) pada siswa Sekolah Dasar yang slow learner dengan menggunakan media the stamp game. Jenis penelitian ini adalah desain eksperimen kasus tunggal. Subjek penelitian meliputi 3 anak slow learner yang dipilih menggunakan teknik purposive sampling. Hasil dari penelitian menunjukkan bahwa media the stamp game dapat meningkatkan kemampuan berhitung (penjumlahan) pada siswa Sekolah Dasar yang slow learner.
\end{abstract}

Kata Kunci: media stamp game, kemampuan berhitung, slow learner

\section{Pendahuluan}

Pendidikan merupakan hak dasar untuk semua anak bahkan dalam situasi apapun tanpa adanya diskriminasi. Hal inilah yang mendasari bahwa pendidikan juga merupakan hak dasar bagi anak berkebutuhan khusus atau yang biasa disebut disabilitas. Isu yang sangat menarik dalam sistem pendidikan nasional adalah mulai berkembangnya sistem pendidikan inklusi yang memberikan kesempatan kepada anak berkebutuhan khusus untuk dapat mengikuti pembelajaran dengan anak normal di sekolah formal (Aziz, Sugirman \& Prabowo, 2015). Salah satu jenjang pendidikan inklusi di Indonesia adalah Sekolah Dasar.
Menurut Santrock masa sekolah dasar merupakan periode perkembangan middle and late childhood (usia 6-11 tahun), dimana anak pada usia ini mulai menguasai keahlian membaca, menulis dan berhitung (Nataliya, 2015).

Berhitung termasuk dalam pelajaran matematika yang terdiri dari penjumlahan, pengurangan, pembagian dan perkalian (Frengky, 2008). Berhitung harus dikuasai sejak awal memasuki Sekolah Dasar karena akan selalu berkaitan dengan pelajaran matematika di kelas-kelas berikutnya bahkan jenjang yang lebih tinggi dari Sekolah Dasar. Jika peserta didik masih mengalami kesulitan dalam berhitung 
akibatnya pelajaran matematika berikutnya akan terasa semakin sulit hingga akhirnya ditakuti bahkan dibenci (Abdurrahman, 2003).

Menurut Susanto (dalam Nataliya, 2015) berhitung merupakan dasar dari berbagai ilmu yang digunakan dalam setiap aktivitas manusia. Pada anak Sekolah Dasar berhitung diperlukan sebagai penunjang keterampilan akademik, selain itu berhitung juga digunakan dalam kehidupan seharihari, contohnya dalam kegiatan transaksi jual beli, pengelolaan uang saku dan mengukur suatu benda, oleh sebab itu kemampuan berhitung sangat penting untuk dimiliki terutama pada masa Sekolah Dasar.

Pada pelaksanaannya tidak semua anak memiliki kemampuan berhitung yang baik, terdapat pula anak yang memiliki kesulitan berhitung, sehingga menghambat prestasi sekolahnya. Menurut Nevid dan Baverly (dalam Ariyanti \& Muslimin, 2015) apabila anak-anak mengalami hambatan perkembangan yang buruk dalam berhitung dan tidak segera ditangani, maka akan menghambat prestasi sekolahnya. Anak yang mengalami hambatan berhitung cenderung berprestasi buruk di sekolah dan sering dinilai gagal oleh guru maupun keluarga anak. Tidak heran jika anak yang memiliki prestasi buruk akan mengembangkan ekspektasi yang rendah dan bermasalah dengan self-esteem.

Jika ditinjau dari perkembangan berhitung secara psikologis menurut NCTM (National Council of Teachers of Mathematics) (dalam Taylor, 2009; Santrock, 2014), pada anak sekolah dasar kemampuan dalam berhitung yang harus dicapai yaitu (1) anak sudah memiliki pemahaman terhadap angka (2) mampu menuliskan bilangan (3) menghubungkan antar bilangan (4) memahami makna operasi hitung dan memahami bagaimana salah satu operasi hitung berhubungan dengan operasi hitung yang lain (5) mampu menghitung melampaui angka 100 (6) menghitung dengan lancar dan membuat perhitungan dengan benar (7) dapat melakukan penjumlahan dan pengurangan. Siswa Sekolah Dasar menurut tahap perkembangan Piaget masuk pada tahap operasional konkret (7-11 tahun), dimana proses berpikir atau tugas mental dapat dikerjakan selama objek masih terlihat, sehingga anak Sekolah Dasar akan lebih mudah dalam menyelesaikan tugas-tugas operasional mencakup tugas penambahan, pengurangan, perkalian, pembagian dan pengurutan apabila menggunakan bantuan media belajar berupa benda konkret (Nataliya, 2015).

Pelajaran Matematika menurut Omrod (dalam Frengky, 2008), dikenal sebagai salah satu mata pelajaran yang menjadi stressor utama dalam proses belajar di sekolah. Pada kelas satu pelajaran matematika berkaitan dengan berhitung sederhana (mulai angka satuan hingga puluhan) namun semakin tinggi tingkat kelas, matematika semakin kompleks dan dirasa sulit (Rakhmawati, 2017). Salah satunya pada standar keterampilan berhitung kelas dua dimana anak mampu berhitung sampai hasil 500 (Ariyanti \& Muslimin, 2015). Berdasarkan standar tersebut maka mulai ditemukan anak-anak yang mengalami kesulitan dalam berhitung baik pada anak normal terlebih lagi pada anak berkebutuhan khusus (Rakhmawati, 2017).

Salah satu individu berkebutuhan khusus yang mengalami kesulitan berhitung adalah slow learner, dimana slow learner mengalami hambatan berhitung karena terbatas dalam memahami konsep abstrak dan simbolis berupa angka dan simbol (Desiningrum, 2016). Pada anak normal, kemampuan berhitung dapat ditingkatkan dengan mem-berikan jam pelajaran tambahan secara intensif, pengulangan oleh guru atau mengikuti bimbingan belajar (Frengky, 2008), namun pada siswa slow learner membutuhkan bantuan khusus berupa media konkret, pengulangan dan pemberian instruksi secara sederhana guna me-ningkatkan kemampuan berhitungnya (Muppudhati, 2017). Oleh sebab itu, anak 
dengan slow learner lebih memerlukan bantuan khusus dari pada anak normal.

Pada anak slow learner skor IQ berada di kisaran 70-89, sehingga slow learner mengalami hambatan kognitif atau keterbatasan potensi kecerdasan (Garnida, 2015). Chauhan (2011) menyatakan bahwa dari total populasi di setiap sekolah sekitar 8 persen merupakan siswa slow learner. Karakteristik dari slow learner menurut Chauhan (2011) yaitu: (1) memiliki kapasitas kognitif yang terbatas, sehingga membutuhkan penjelasan dan instruksi secara sederhana untuk memudahkan anak memahami sebuah konsep; (2) memiliki memori yang terbatas, anak membutuhkan waktu yang lebih lama dan lebih banyak pengulangan dalam memahami sebuah konsep; (3) kesulitan dalam mempertahankan konsentrasi; (4) kesulitan dalam mengungkapkan ide, mengingat pesan dan mendengarkan instruksi; (5) memiliki kecerdasan dan prestasi akademik yang rendah; (6) sangat terbatas dalam menangani konsep yang bersifat abstrak dan simbolis (bahasa, angka dan konsep). Pada aspek sosial dan emosi menurut Desiningrum (2016) adanya keterbatasan slow learner dalam belajar membuat anak mendapatkan label yang kurang baik dari teman-temannya sehingga pada anak tumbuh perasaan minder, anak cenderung bersikap pemalu dan menarik diri dari lingkungan sosialnya. Pada aspek fisik menurut Malik, Rehman, dan Hanif (2012), slow learner mempunyai penampilan yang sama seperti anak normal, sehingga karakteristik slow learner baru akan tampak ketika anak menghadapi tugas-tugas yang menuntut konsep abstrak, simbolsimbol, dan keterampilan konseptual.

Berdasarkan penelitian Mumpuniarti (2017) kemampuan operasi hitung pada siswa slow learner di kelas bawah (2-3) Sekolah Dasar diketahui masih pada kemampuan menjumlah dengan hasil penjumlahan dibawah angka 50 sedangkan pada penjumlahan, pengurangan, perkalian dan pembagian kemampuan anak slow learner masih dibawah standar, yaitu sampai pada hasil penghitungan di angka 50 dan kadang-kadang hanya sampai 30 . Menurut Abdurrahman (2003), keterampilan tentang penjumlahan merupakan dasar untuk semua keterampilan operasi hitung, oleh sebab itu kesulitan dalam menerima pelajaran penjumlahan pada siswa slow learner menjadi langkah pertama yang harus ditangani terlebih dahulu. Penelitian ini berfokus pada peningkatan kemampuan berhitung penjumlahan mulai dari satuan sampai puluhan dengan hasil di bawah 50 hingga 99. Pemilihan batasan tersebut dikarenakan kemampuan anak slow learner masih pada penjumlahan dengan hasil dibawah 50, sehingga diperlukan adanya pemberian materi secara bertahap dan berulang-ulang agar anak slow learner mampu memahami dengan benar serta dapat mempertahankan materi yang telah dipelajari pada ingatan anak.

Keterampilan berhitung menjadi penting sebagai sarana untuk memecahkan masalah dalam kehidupan sehari-hari (Abdurrohman, 2003). Pada anak slow learner keterampilan berhitung berfungsi untuk diterapkan dalam kehidupan seharihari misalnya untuk melakukan pembelian, pengelolaan uang saku untuk kepentingan konsumsi, menabung, melakukan tukar antar pecahan uang dengan teman dan menghitung barang-barang yang dimiliki. Menurut Desiningrum (2016) dampak psikologis bagi anak slow learner dengan prestasi rendah akibat memiliki hambatan dalam berhitung adalah anak akan cenderung mendapatkan label yang kurang baik dari teman-temannya, sehingga muncul perasaan minder, anak cenderung bersikap pemalu dan menarik diri dari lingkungan sosialnya. Hasil prestasi belajar yang kurang optimal dapat membuat anak menjadi stres karena ketidakmampuan dalam mencapai apa yang diharapkannya. Apalagi ketika orang tua memberikan harapan lebih terhadap anak sehingga tanpa disadari sikap orang tua akan menambah beban psikologis anak. 
Anak slow learner sebaiknya mengikuti pembelajaran di sekolah umum karena masih memungkinkan untuk belajar menggunakan kurikulum di sekolah umum dengan tetap memerlukan penyesuaian pada aspek program pembelajaran (Mumpuniarti, Rudiyati, Sukinah \& Cahyaningrum, 2014). Anak slow learner membutuhkan intruksi khusus yang disampaikan secara berulang, sederhana, pemberian umpan balik, dan pengaturan sumber belajar khusus seperti media yang diciptakan untuk meningkatkan kemampuan belajar anak (Dasaradhi, Rajeswari \& Badarinath, 2016; Muppudhati, 2017). Untuk membantu anak slow learner dalam memahami konsep abstrak berupa hitungan, maka diperlukan metode belajar yang menyediakan media berbentuk konkret/ nyata guna meningkatkan kemampuan berhitung (penjumlahan) pada anak. Salah satu metode belajar yang menggunakan media konkret adalah metode Montessori, yaitu metode belajar yang menyelenggarakan pembelajaran menggunakan alat peraga/benda nyata (Lillard, 2013). Peneliti memilih metode Montessori karena dalam pembelajarannya menggunakan media konkret untuk mengajarkan suatu konsep salah satunya adalah berhitung, sehingga melalui metode ini diharapkan dapat menjembatani anak slow learner dalam memahami konsep berhitung (penjumlahan).

Menurut Irving (2017) metode Montessori memiliki berbagai media belajar berbentuk konkret. Media atau alat peraga pada metode Montessori biasa disebut dengan aparatus Montessori (Kusumo, 2016). Stamp game adalah sebuah alat peraga yang memiliki konsep untuk mengajarkan operasi hitung salah satunya penjumlahan, selain itu stamp game juga digunakan untuk membantu anak dalam memahami nilai tempat (Irving, 2017).

Stamp game memiliki karakteristik yaitu (1) menarik, didesain dengan menyediakan stamp angka dengan warna yang berbeda-beda sesuai tingkatan angka. Anak dibuat tertarik untuk melihat, menyentuh, meraba dan memegangnya sehingga alat peraga ini diarahkan untuk pengembangan panca indra anak; (2) bergradasi, terkait dengan warna, bentuk, dan usia anak, stamp game dapat mulai digunakan pada siswa sekolah dasar dan digunakan untuk pembentukan konsep belajar berhitung penjumlahan; (3) autocorrection, yaitu memiliki pengendali kesalahan (kunci jawaban); (4) autoeducation, yaitu dapat mengembangkan kemampuan anak untuk belajar secara mandiri; (5) kontekstual, yaitu dikhususkan untuk memenuhi kebutuhan anak dalam berlatih kemampuan berhitung salah satunya penjumlahan. Stamp game juga bersifat konkret yaitu dapat dieksplorasi oleh indera anak karena dapat disentuh, dipegang, dan digunakan langsung oleh anak (Mariyah, Aprinastuti, \& Anggadewi, 2017).

Kelebihan dari stamp game yaitu (1) dapat digunakan sebagai pendukung bagi mata pelajaran yang dirasa lemah, sehingga anak slow learner yang mengalami kesulitan dalam berhitung penjumlahan dapat ditingkatkan kemam-puannya melalui media ini; (2) wujud media stamp game yang berbentuk konkret dan sederhana dapat membantu anak slow learner guna memudahkan dalam memahami konsep abstrak khususnya berhitung penjumlahan; (3) penggunaan media stamp game dapat dilakukan secara berulang-ulang secara mandiri karena bagi anak slow learner perlu lebih banyak pengulangan dalam memahami konsep baru; (4) dapat digunakan untuk meningkatkan kemampuan berhitung penjumlahan mulai dari angka satuan hingga ribuan sesuai dengan kebutuhan anak yang ingin ditingkatkan dan memahamkan anak terhadap nilai tempat (Mariyah, Aprinastuti, \& Anggadewi, 2017). 
Berdasarkan keterbatasan slow learner yaitu kesulitan memahami konsep abstrak dan simbolis, maka media stamp game yang berwujud konkret, memiliki cara penggunaan yang sederhana dan dapat dilakukan pengulangan, dirasa sesuai untuk digunakan dalam mengatasi kesulitan anak slow learner dalam memahami konsep abstrak, khususnya berhitung (penjumlahan). Stamp game memiliki karakteristik menarik dan bergradasi, yaitu dapat digunakan untuk mengembangkan panca indera anak slow learner karena didesain dengan memperhatikan warna pada stamp angka yang dibedakan sesuai tingkatan angka mulai dari satuan hingga ribuan, sehingga secara tidak langsung anak dibuat tertarik untuk melihat, menyentuh dan memegangnya. Stamp game juga memiliki karakteristik kontekstual, yaitu dikhususkan untuk memenuhi kebutuhan anak dalam berhitung, sehingga anak slow learner yang awalnya hanya mampu menjumlahkan dengan hasil kurang dari 50, akan berlatih untuk meningkatkan kemampuan berhitungnya. Sesuai dengan karakteristik stamp game yakni auto-education, maka anak slow learner dapat berlatih mengembangkan kemampuan ber-hitung penjumlahan secara mandiri. Anak slow learner juga dapat mengoreksi hasil pekerjaannya dengan melihat kunci jawaban setelah selesai mengerjakan soal penjumlahan sesuai dengan karakteristik autocorrection.

Stamp game berbentuk sebuah kotak yang didalamnya terdapat empat ruang, dua ruang berisi stamp yaitu kartu angka berbentuk kepingan persegi berukuran $1 \mathrm{~cm}$ $\mathrm{X} 1 \mathrm{~cm}$. Stamp terdiri dari dua warna, stamp hijau dengan tanda 1 dimaknai sebagai angka puluhan sedangkan stamp biru dengan tanda 10 dimaknai sebagai angka puluhan. Satu kotak lain berisi kartu soal dan satu kotak lainnya berisi kunci jawaban, stamp game juga dilengkapi dengan papan untuk mengerjakan soal penjumlahan yang terdiri dari dua kolom, yaitu kolom satuan berwarna hijau dan puluhan berwarna biru serta dilengkapi buku panduan penggunaan atau modul.

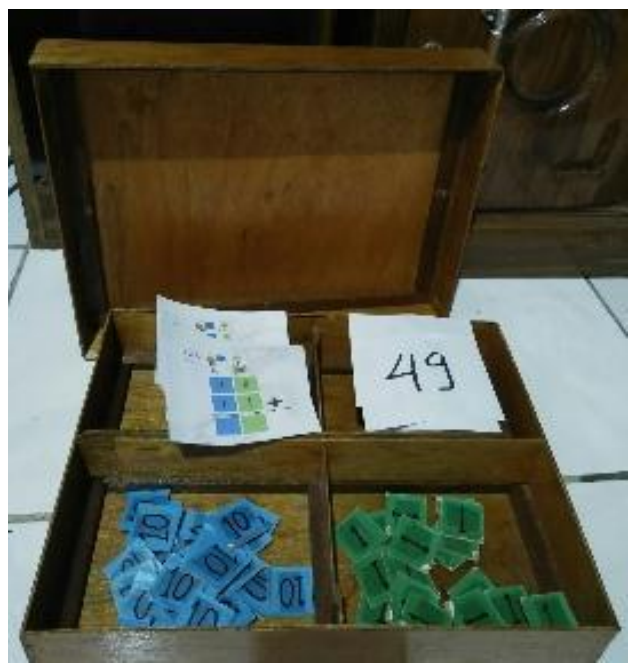

Gambar 1. Kotak media stamp game

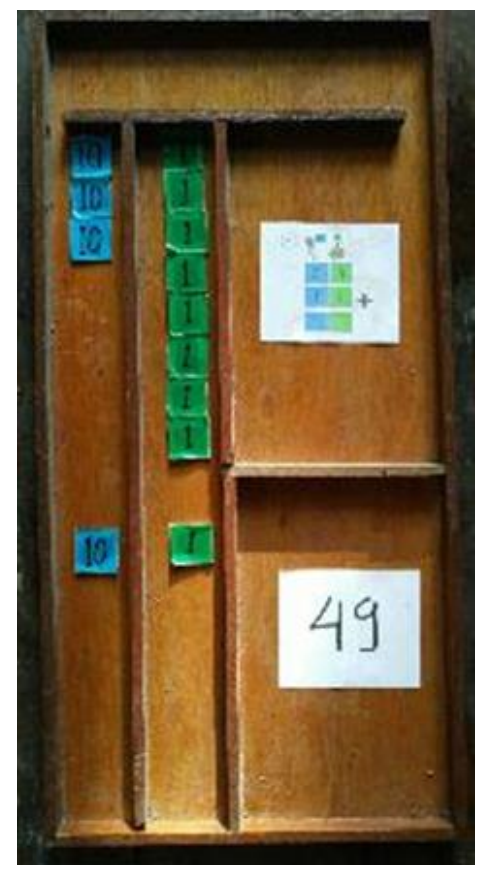

Gambar 2. Papan penjumlahan

Berdasarkan panduan penggunaan media stamp game, tahapan dari media ini yaitu: (1) anak mengambil kartu soal dan mengamati soal yang tertera pada angka, cara pengerjaan harus dimulai dari angka satuan terlebih dahulu; (2) anak mulai mengambil stamp angka sesuai dengan angka penjumlahan yang tertera pada kartu soal; (3) anak mulai menyusun stamp angka pada papan pengerjaan secara urut sesuai 
dengan nilai tempat dan warna stamp angka, misalkan $23+15$ maka anak mengambil tiga buah stamp angka satuan (stamp angka yang ditandai angka 1) berwarna hijau dan menyusun pada papan pengerjaan di kolom satuan berwarna hijau secara vertikal, setelah itu anak kembali mengambil lima buah stamp angka satuan kemudian menyusun secara vertikal di bawah tiga stamp angka yang telah anak susun sebelumnya dengan memberi jarak antara susunan tiga stamp angka dengan lima stamp angka sekitar $3 \mathrm{~cm}$; (4) selanjutnya beralih menyusun pada angka puluhan, anak mengambil dua stamp angka puluhan (stamp angka yang ditandai angka 10) berwarna biru dan menyusun pada papan pengerjaan di kolom puluhan berwarna biru secara vertikal, setelah itu anak kembali mengambil satu buah stamp angka puluhan kemudian menyusun secara vertikal di bawah dua stamp angka puluhan yang telah anak susun sebelumnya dengan memberi jarak antara susunan dua stamp angka puluhan dengan satu stamp angka puluhan sekitar $3 \mathrm{~cm}$; (5) Langkah selanjutnya adalah melakukan penjumlahan dengan mendahulukan penghitungan pada angka satuan dan dilanjutkan menjumlahkan angka puluhan; (6) langkah terakhir menuliskan hasil penghitungan yakni 38 pada kolom jawaban.

Penelitian mengenai penggunaan media stamp game untuk meningkatkan kemampuan berhitung (penjumlahan) pada anak slow learner belum pernah dilakukan sebelumnya. Wiropati (2015) melakukan penelitian mengenai peningkatan kualitas pembelajaran matematika materi penjumlahan sampai dengan bilangan 100 dengan menggunakan media audio visual bagi anak slow learner kelas 2 di SDN Pajang I Surakarta (sekolah inklusi). Penelitian dilakukan pada 8 subjek dengan satu kali pengambilan nilai sebelum diberikan intervensi dan dua siklus penilaian setelah diberikan intervensi. Pengambilan nilai dilakukan dari hasil tes objektif pada setiap subjek. Hasil penelitian menunjukkan bahwa pada pengambilan nilai sebelum diberikan intervensi media audio visual, terdapat 5 siswa yang memperoleh nilai kurang dari 60 atau belum tuntas belajarnya dan hanya 3 siswa yang mendapatkan nilai 60 atau lebih, sehingga ketuntasan secara klasikal mencapai $37.50 \%$. Pada pengambilan nilai siklus I, setelah diberikan intervensi menggunakan media audio visual terdapat 5 siswa memperoleh nilai 60 atau lebih dan 3 siswa memperoleh nilai di bawah 60, sehingga ketuntasan secara klasikal mencapai $62.50 \%$. Pada siklus II, diketahui seluruh subjek mendapatkan nilai 60 atau lebih dengan ketuntasan secara klasikal telah mencapai $100 \%$.

Perbedan penelitian ini dengan penelitian sebelumnya adalah pada penelitian yang dilakukan Wiropati (2015) media yang digunakan berupa audio visual sehingga media ini termasuk tidak menggunakan alat peraga yang berbentuk konkret/nyata karena media tidak dapat dapat disentuh atau dipegang oleh anak slow learner, sedangkan pada penelitian ini menggunakan media stamp game, dimana media yang digunakan berbentuk konkret/nyata dan dapat disentuh maupun dipegang oleh anak slow learner. Menurut Mumpuniarti (2014), saat ini cara mengajarkan Matematika terutama berhitung yang dilakukan guru adalah dengan mempergunakan buku dan sumber belajar yang mudah dipahami oleh anak slow learner, selain itu guru juga menggunakan media gambar dan alat peraga yang mudah disentuh anak slow learner untuk melakukan hitungan.

Berdasarkan uraian di atas, rumusan masalah yang akan diangkat dalam penelitian ini adalah apakah media stamp game dapat digunakan untuk meningkatkan kemampuan operasi hitung (penjumlahan) pada siswa sekolah dasar yang slow learner? Tujuan penelitian ini adalah untuk meningkatkan kemampuan operasi hitung (penjumlahan) pada siswa sekolah dasar yang slow learner dengan menggunakan media stamp game. Manfaat penelitian ini 
adalah pertama, mendapatkan usulan model intervensi bagi siswa sekolah dasar yang slow learner dalam hal peningkatan kemampuan operasi hitung (penjumlahan). Kedua, dapat memberikan kontribusi bagi sekolah dasar dan guru kelas dalam menangani siswa slow learner agar memiliki kemampuan yang lebih baik dalam melakukan operasi hitung (penjumlahan).

\section{Metode Penelitian}

\section{Rancangan Penelitian}

Penelitian ini menggunakan pendekatan kuantitatif dengan desain eksperimen kasus tunggal (single-case experimental design). Menurut Kazdin (dalam Latipun, 2015) desain eksperimen kasus tunggal (single-case experimental design) adalah sebuah desain penelitian untuk mengevaluasi efek suatu perlakuan (intervensi) dengan kasus tunggal. Kasus tunggal dapat berupa beberapa subjek dalam satu kelompok atau subjek yang diteliti adalah tunggal $(\mathrm{N}=1)$ (Latipun, 2015).

Kategori dari desain eksperimen kasus tunggal yang digunakan pada penelitian ini adalah desain A-B-A withdrawal. Desain A-B-A pada dasarnya melibatkan fase baseline (A) dan fase perlakuan (B). Withdrawal berarti menghentikan perlakuan dan kembali kepada baseline (Latipun, 2015). Desain A-B-A withdrawal memiliki sejumlah variasi desain, peneliti memilih menggunakan desain A-B-A sebagai desain penelitian yang akan digunakan. Desain AB-A. terdiri dari tiga fase yakni, pertama baseline A1 yaitu kondisi dimana pengukuran target perlakuan dilakukan dalam keadaan natural sebelum diberikan perlakuan/ intervensi apapun. Kedua, perlakuan (B) yaitu kondisi dimana dilakukan pemberian intervensi dengan menggunakan media "stamp game" dan ketiga, fase baseline A2 atau disebut pasca intervensi yaitu kondisi dimana dilakukan pengukuran terhadap target perlakuan setelah tidak lagi diberikan intervensi. Penambahan kondisi pasca intervensi (baseline A2) ini dimaksudkan sebagai kontrol untuk fase intervensi sehingga memungkinkan untuk menarik kesimpulan adanya hubungan fungsional antara variabel bebas dan variabel terikat (Sunanto, Takeuchi \& Nakata, 2005). Menurut Latipun (2015) apabila selama fase perlakuan hasil pengukuran target perlakuan menunjukkan perbedaan dibandingkan dengan selama fase baseline A1, maka dipandang sebagai efek dari suatu perlakuan yang telah diberikan (Latipun, 2015). Rancangan penelitian digambarkan pada gambar 3 .

Fase A1 (baseline A1) adalah kondisi dimana pengukuran target perlakuan dilakukan dalam keadaan natural sebelum diberikan perlakuan/intervensi apapun. Fase B (perlakuan) adalah kondisi dimana dilakukan pemberian perlakuan/ intervensi dengan menggunakan media "stamp game", setelah intervensi diberikan maka dilakukan pengukuran pada target perlakuan untuk mengukur keberhasilan dari intervensi yang baru saja diberikan. Fase A2 (baseline A2 atau pasca intervensi) yaitu kondisi dimana kembali dilakukan pengukuran terhadap target perlakuan setelah tidak lagi diberikan intervensi.

\section{Subjek Penelitian}

Pada penelitian ini pemilihan subjek menggunakan teknik purposive sampling yaitu pemilihan sampel sesuai dengan yang dikehendaki peneliti (Latipun, 2015). Subjek penelitian ini adalah tiga siswa kelas dua SDN TW 3 Kota Malang (sekolah inklusi) dengan kriteria yaitu, (1) memiliki usia antara 7-10 tahun; (2) memiliki kemampuan berhitung penjumlahan yang rendah dengan hasil di bawah 50 yang diketahui berdasarkan pemberian tes berhitung (penjumlahan) pada subjek; (3) memiliki IQ dengan kisaran 70-89 yang diketahui berdasarkan tes inteligensi Binet; (4) teridentifikasi slow learner berdasarkan asesmen yang dilakukan melalui wawancara dan observasi.

\section{Variabel dan Instrumen Penelitian}

Pada penelitian ini terdapat dua variabel yakni variabel $\mathrm{X}$ atau bebas 
(independent) dan variabel $\mathrm{Y}$ atau terikat (dependent). Pada penelitian eksperimen kasus tunggal variabel bebas dikenal dengan istilah intervensi atau perlakuan, sedangkan variabel terikat dikenal dengan nama perilaku sasaran atau target perlakuan. Pada penelitian ini yang menjadi variabel bebas (X) adalah media stamp game yaitu sebuah media atau alat peraga yang memiliki konsep untuk mengajarkan operasi hitung penjumlahan. Media stamp game dimodifikasi dengan memba-tasi penjumlahan dari angka satuan hingga puluhan dengan hasil penjumlahan sampai angka 99. Variabel terikat (Y) dalam penelitian ini adalah kemampuan berhitung penjumlahan, yaitu kemampuan melakukan pengerjaan menjumlah pada bilangan untuk menentukan hasil penjumlahan dari dua bilangan. Pada siswa slow learner kelas 2 Sekolah Dasar kemampuan operasional hitung penjumlahan diketahui masih dibawah standar, yaitu sampai pada hasil penghitungan dibawah angka 50 .

Pengambilan data dilakukan dengan menggunakan tes objektif penjumlahan. Data penelitian diperoleh dari instrumen penelitian menggunakan model pengukuran dengan memberikan tes objektif berupa soal penjumlahan. Soal-soal penjumlahan disusun oleh peneliti dan disesuaikan dengan materi pembelajaran di kelas 2 SD. Menurut Arikunto (2007) Tes objektif adalah tes yang dalam pemeriksaannya dapat dilakukan secara objektif. Tes objektif bersifat pasti karena hanya memiliki satu kemungkinan jawaban yang benar. Apabila respon sesuai dengan jawaban yang dikehendaki maka respon tersebut benar dan diberi skor 1, namun apabila respon tidak sesuai dengan jawaban yang dikehendaki maka respon tersebut salah dan diberi skor 0. Pada penelitian ini, jenis tes objektif yang digunakan adalah tes objektif jawaban singkat, yaitu dengan menuliskan angka dari hasil penghitungan penjumlahan. Pengukuran dilakukan dengan mengumpulkan skor hasil pengerjaan soal penjumlahan subjek pada saat baseline
A1, pemberian intervensi (B) dan saat pasca intervensi. Pada penelitian ini, peneliti juga menggunakan observasi, dimana peneliti melakukan pengamatan dan mencatat perilaku apa saja yang muncul selama penelitian berlangsung.

Pada tahap baseline A1 dan pasca intervensi tes objektif terdiri dari 10 soal dengan variasi soal yang sama pada setiap sesinya, sedangkan pada tahap intervensi tes objektif terdiri dari 10 soal dengan variasi soal yang berbeda tiap sesinya. Variasi soal penjumlahan disusun secara bertahap mulai dari penjumlahan dengan hasil di bawah 50 hingga di bawah angka 100. Kriteria penilaian yang digunakan yaitu skor 1 diberikan jika subjek mampu menjawab satu soal dengan benar dan skor 0 diberikan jika subjek tidak mampu menjawab satu soal dengan benar.

\section{Prosedur dan Analisa Data}

Penelitian ini dilakukan dalam rentang waktu dua bulan. Secara umum, penelitian yang dilakukan terdiri dari tiga prosedur utama yaitu persiapan, pelaksanaan dan analisa data. Tahap persiapan, dimulai dari pembuatan rancangan penelitian berupa proposal penelitian kemudian menyusun instrumen penelitian berupa modul dan tes objektif penjumlahan. Peneliti menyusun tes objektif penjumlahan berdasarkan pengembangan dari buku ESPS (Erlangga Straight Point Series) Matematika untuk SD/MI Kelas II yang disusun oleh Gunanto dan Adhalia (2016) dan buku Terampil Berhitung Matematika untuk SD/MI Kelas II yang disusun oleh Tim Bina Karya Guru (2014). Soal penjumlahan yang disusun tersebut telah dilakukan penyesuaian kembali agar sesuai dengan karakteristik dan kemampuan yang ingin ditingkatkan pada anak slow learner yaitu penjumlahan dari angka satuan hingga puluhan, sehingga nantinya tes objektif tersebut dapat digunakan sebagai alat ukur yang tepat dan sesuai bagi anak slow learner untuk mengetahui ada tidaknya peningkatan kemampuan berhitung penjumlahan sebelum dan sesudah intervensi. 
Langkah selanjutnya adalah peneliti memilih tempat penelitian dan menentukan subjek penelitian dengan melakukan asesmen sebanyak empat langkah, pertama peneliti melakukan wawancara terhadap pihak sekolah yaitu guru kelas atau guru pendamping khusus untuk mengetahui adanya siswa Sekolah Dasar yang mengalami kesulitan berhitung.

Kedua, peneliti melakukan asesmen dengan memberikan tes penjumlahan pada siswa terpilih dari hasil asesmen wawancara dengan memberi-kan tes yang terdiri dari 10 soal dengan hasil penjumlahan di bawah 50. Tes objektif dilakukan untuk mengetahui ke-mampuan berhitung (penjumlahan) pada subjek. Tes dilakukan sebanyak dua kali pertemuan di waktu yang berbeda sebagai penguat tes yang pertama. Apabila dari dua kali pengerjaan tes subjek memperoleh skor sama dengan 4 atau dibawahnya, maka siswa tersebut dikategorikan sebagai anak dengan kemampuan berhitung penjumlahan yang rendah.

Ketiga, peneliti melakukan observasi pada siswa terpilih dari hasil asesmen tes dengan mencocokkan karak-teristik siswa dengan karakteristik anak slow learner.

Keempat, peneliti melakukan tes kecerdasan menggunakan tes Binet pada siswa terpilih, jika hasil tes kecerdasan pada siswa menunjukkan hasil IQ dengan rentang 70-89 maka siswa tersebut berada dalam kategori slow learner dan telah sesuai dengan kriteria subjek penelitian. Selanjutnya peneliti menyusun jadwal kegiatan dan menyiapkan alat instrumen penelitian berupa media stamp game. Kemudian menyiapkan peralatan yang diperlukan dalam pelaksanaan penelitian. Sebelum memberikan perlakuan yang sesungguhnya, peneliti melakukan tryout pada subjek yang berbeda dengan karakteristik yang sama dengan subjek penelitian untuk mengetahui kelayakan dari modul penelitian.

Tahap pelaksanaan, dimulai dengan peneliti meminta subjek mengerjakan tes objektif penjumlahan untuk mengetahui data awal (baseline) masing-masing subjek. Pelaksanaan baseline A1 dilakukan sebanyak tiga pertemuan dengan durasi 60 menit perpertemuan agar peneliti mendapatkan data baseline yang stabil. Apabila data awal sudah diketahui, kemudian peneliti melaksanakan intervensi sesuai dengan jadwal kegiatan yang telah disusun. Pada tahap intervensi, peneliti memberikan suatu perlakuan dengan cara mengajarkan penjumlahan menggunakan media stamp game untuk meningkatkan kemampuan subjek dalam berhitung penjumlahan. Pemberian intervensi dilakukan secara individu, tiap subjek diberikan perlakuan dengan durasi 80 menit perpertemuan (20 menit untuk intervensi dan 60 menit untuk pemberian tes objektif) yang dilakukan selama enam kali. Prosedur intervensi metode Montessori media stamp game, pertama peneliti mengajarkan terlebih dahulu cara penggunaan media stamp game kepada subjek, selanjutnya subjek diminta untuk belajar menggunakan media stamp game. Selama intervensi berlangsung peneliti akan membimbing subjek jika

$$
\mathrm{O} \Rightarrow \mathrm{O} \Rightarrow \mathrm{O} \Rightarrow \quad \mathrm{X} \Rightarrow \mathrm{O} \Rightarrow \mathrm{X} \Rightarrow \mathrm{O} \Rightarrow \mathrm{X} \Rightarrow \mathrm{O} \Rightarrow \mathrm{X} \Rightarrow \mathrm{O} \Rightarrow \mathrm{X} \Rightarrow \mathrm{O} \Rightarrow \mathrm{X} \Rightarrow \mathrm{O} \Rightarrow \mathrm{O} \Rightarrow \mathrm{O} \Rightarrow \mathrm{O}
$$

Gambar 3. Rancangan penelitian

Keterangan:

$\mathrm{O}:$ Pengukuran target perlakuan.

$\mathrm{X}$ : Perlakuan/intervensi menggunakan media "stamp game". 
terdapat kesalahan penggunaan media maupun kesalahan dalam menjumlahkan. Selanjutnya setelah proses intervensi selesai dan dirasa subjek telah mampu menggunakan media stamp game dengan benar, maka subjek diberikan tes objektif untuk mengukur keberhasilan dari intervensi yang baru saja dilakukan. Proses intervensi berakhir pada pasca intervensi yaitu melakukan pengukuran kembali pada masing-masing subjek sebanyak tiga pertemuan dengan memberikan tes objektif yang sama dengan baseline A1 setelah keseluruhan intervensi selesai dilakukan.

Tahap analisa data, setelah proses pengumpulan data selesai dilakukan maka data dianalisis kemudian dipresentasikan ke dalam grafik garis dengan tujuan untuk mempermudah dan memperjelas gambaran dari pelaksanaan eksperimen pada saat baseline $\mathrm{A} 1$, intervensi dan pasca intervensi. Proses analisis data pada penelitian subjek tunggal banyak mempresentasikan data ke dalam grafik khususnya grafik garis, dengan menampilkan grafik peneliti akan lebih mudah untuk menjelaskan perilaku subjek secara efisien dan detail (Sunanto, Takeuchi, \& Nakata, 2005). Teknik analisa data yang digunakan dalam penelitian ini adalah analisis statistik deskriptif sederhana dengan melakukan pengamatan secara langsung terhadap data yang ditampilkan dalam grafik. Pada penelitian eksperimen dengan kasus tunggal penggunaan statistik yang komplek tidak dilakukan tetapi lebih banyak menggunakan statistik deskriptif yang sederhana. Penelitian dengan kasus tunggal terfokus pada data individu dari pada data kelompok, meskipun demikian data kelompok kadang-kadang juga digunakan (Sunanto, Takeuchi, \& Nakata, 2005).

Analisa data dilakukan untuk mengetahui ada tidaknya perbedaan kemampuan subjek dalam berhitung (penjumlahan) sebelum dan sesudah intervensi serta untuk membuktikan hipotesis yang ada. Pengaruh dari perlakuan yang telah diberikan akan diketahui dengan menggunakan perbandingan dari hasil baseline A1 dengan pada saat intervensi (B) dan pasca intervensi, sehingga akan terlihat perbedaan sebelum dan sesudah diberikan intervensi. Jika pada saat intervensi (B) dan pasca intervensi subjek mendapatkan skor lebih tinggi dibandingkan pada saat baseline (A1), maka dapat dinyatakan bahwa terdapat peningkatan kemampuan berhitung penjumlahan pada subjek. Hasil analisa data akan dideskripsikan menggunakan bahasa yang sederhana, jelas dan mudah dimengerti (Latipun, 2015).

\section{Hasil Penelitian dan Pembahasan}

Pada penelitian ini, karakteristik subjek yang terlibat dalam penelitian dengan media stamp game dapat dilihat pada tabel 1. Pada tabel 1 dapat diketahui bahwa ketiga subjek penelitian yakni $\mathrm{G}, \mathrm{H}$ dan $\mathrm{M}$ berdasarkan asesmen telah memenuhi kriteria subjek penelitian berdasarkan kriteria jenis kelamin, pendidikan, usia, skor IQ dan tingkat kemampuan berhitung. subjek.

Tabel 1

Karakteristik Subjek Penelitian

\begin{tabular}{cccccc}
\hline Nama & $\begin{array}{c}\text { Jenis } \\
\text { Kelamin }\end{array}$ & Pendidikan & $\begin{array}{c}\text { Usia } \\
\text { (Tahun) }\end{array}$ & Skor IQ & $\begin{array}{c}\text { Tingkat Kemampuan } \\
\text { Berhitung }\end{array}$ \\
\hline G & Laki-laki & SDN TW 3 (Kelas II) & 9 & 77 & Rendah \\
H & Perempuan & SDN TW 3 (Kelas II) & 8 & 75 & Rendah \\
M & Laki-laki & SDN TW 3 (Kelas II) & 10 & 71 & Rendah \\
\hline
\end{tabular}




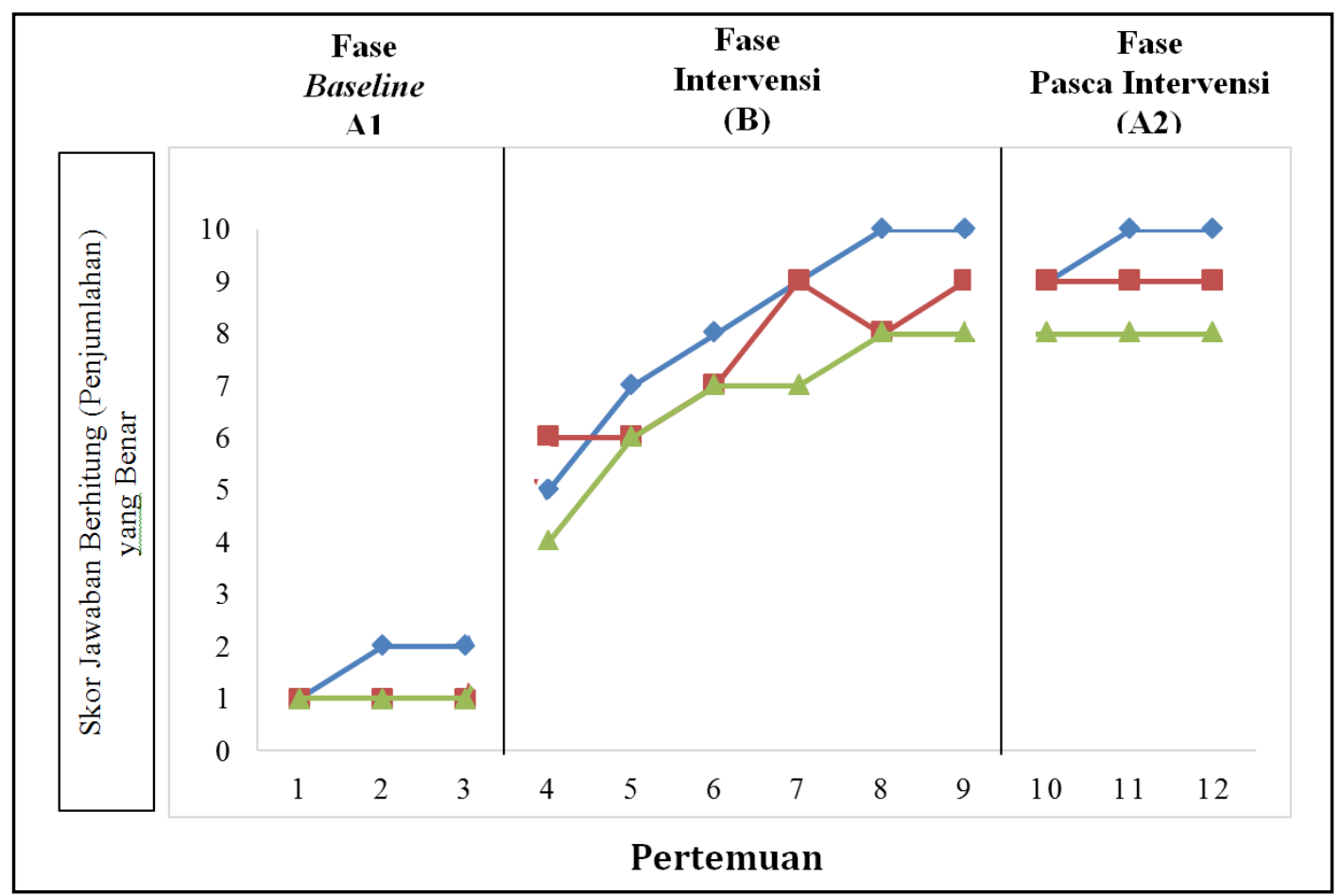

Gambar 4. Grafik hasil intervensi subjek G, H dan M pada fase baseline A1, intervensi, pasca intervensi.

Keterangan:

Subjek G Subjek H Subjek M

\section{Hasil Intervensi Subjek G, H, dan M}

Hasil intervensi subjek $\mathrm{G}, \mathrm{H}$, dan $\mathrm{M}$ mengenai kemampuan berhitung (penjumlahan) yang ditingkatkan melalui media stamp game dapat dilihat pada gambar 4. Berdasarkan gambar 4 di atas, diketahui bahwa terdapat peningkatan perolehan skor kemampuan berhitung (penjumlahan) pada ketiga subjek sebelum diberikan intervensi (baseline A1) dan pasca intervensi menggunakan media stamp game.

Berdasarkan analisis grafik di atas dapat diketahui hasil rata-rata perolehan skor dari fase baseline A1 dan pasca intervensi pada ketiga subjek. Subjek G pada baseline A1 memperoleh skor 1.67 dan pada pasca intervensi memperoleh skor 9.67, sehingga terjadi peningkatan sebesar 8. Subjek H pada baseline A1 memperoleh skor 1 dan pada pasca intervensi memper- oleh skor 9, sehingga terjadi peningkatan sebesar 8. Subjek M pada baseline A1 memperoleh skor 1 dan pada pasca intervensi memperoleh skor 8 , sehingga terjadi peningkatan sebesar 7 .

Pada fase baseline A1 (sebelum diberikan perlakuan) pertemuan ke-1, ke-2 dan ke-3, dari hasil uji dengan soal berhitung (penjumlahan) diketahui bahwa ketiga subjek memiliki perolehan skor yang rendah (dibawah standar nilai 4). Pada subjek $\mathrm{G}$ pertemuan ke-1 memperoleh skor 1, lalu pada pertemuan ke-2 dan ke-3 subjek memperoleh skor yang stagnan (sama) yakni dalam waktu dua kali berturut-turut memperoleh skor 2 di masing-masing pertemuan. Subjek $\mathrm{H}$ dan M, pada pertemuan ke-1, ke-2 dan ke-3 diperoleh hasil yang stagnan, yakni selama tiga kali pertemuan secara berturut-turut 
subjek $\mathrm{H}$ memperoleh skor 1 di masingmasing pertemuan dan subjek $M$ juga selama tiga kali pertemuan secara berturutturut memperoleh skor 1 di masing-masing pertemuan.

Pada fase intervensi, dimana subjek diberikan perlakuan dengan media stamp game, terlihat bahwa terjadi trend peningkatan kemampuan berhitung (penjumlahan) dari fase baseline A1 dan fase intervensi. Pada fase intervensi pertemuan ke-4 ketiga subjek mengalami trend peningkatan dari pertemuan sebelumnya, peningkatan terbesar ada pada subjek $\mathrm{H}$ dengan skor 6 , lalu urutan kedua ada pada subjek $\mathrm{G}$ dengan skor 5 dan urutan ketiga ada pada subjek $M$ dengan skor 4 . Pada pertemuan ke-5, terdapat dua subjek yang mengalami trend peningkatan dari pertemuan sebelumnya, yakni subjek $G$ dengan skor 7 dan subjek M dengan skor 6, dan pada subjek $\mathrm{H}$ diperoleh hasil yang stagnan (sama) dengan pertemuan sebelumnya yakni mendapatkan skor 6. Pada pertemuan ke-6 ketiga subjek mengalami trend peningkatan dari pertemuan sebelumnya, subjek $G$ dengan perolehan skor 8 , subjek $\mathrm{H}$ dengan skor 7 dan subjek $\mathrm{M}$ juga dengan skor 7. Pada pertemuan ke-7, terdapat dua subjek yang mengalami trend peningkatan dari pertemuan sebelumnya, yakni subjek $\mathrm{G}$ dengan skor 9 dan subjek $\mathrm{H}$ dengan skor 9, dan pada subjek M diperoleh hasil yang stagnan (sama) dengan pertemuan sebelumnya yakni mendapatkan skor 7.

Pada pertemuan ke-8 terdapat dua subjek yang mengalami tren peningkatan dari pertemuan sebelumnya, yakni subjek $\mathrm{G}$ dengan skor 10 dan subjek $M$ dengan skor 8 , namun pada subjek $\mathrm{H}$ mengalami tren penurunan dari pertemuan sebelumnya yakni mendapatkan skor 8 . Tren penurunan pada subjek $\mathrm{H}$ dapat terjadi karena subjek kurang berkonsentrasi selama intervensi karena tertarik dengan mainan yang ada pada rak dalam ruang intervensi, sehingga saat subjek kembali pada soal subjek lupa tidak menambahkan simpanan pada soal penjumlahan dengan menyimpan. Pada pertemuan ke-9, subjek $\mathrm{H}$ mengalami tren peningkatan dari pertemuan sebelumnya dengan skor 9, dan pada subjek $G$ dan $M$ diperoleh hasil yang stagnan (sama) dengan pertemuan sebelumnya yakni pada subjek $\mathrm{G}$ mendapatkan skor 10 dan subjek $\mathrm{M}$ memperoleh skor 9 .

Pada fase pasca intervensi (sesudah diberikan perlakuan) yang mana subjek mengerjakan soal penjumlahan tanpa menggunakan media stamp game, pada pertemuan ke-10 subjek $\mathrm{G}$ mengalami trend penurunan dari pertemuan sebelumnya dengan skor 9, penurunan tersebut dapat terjadi karena subjek terlupa tidak menambahkan simpanan saat mengerjakan soal penjumlahan dengan menyimpan. Selanjutnya pada subjek $\mathrm{H}$ dan $\mathrm{M}$ diperoleh hasil yang stagnan (sama) dengan pertemuan sebelumnya, yakni pada subjek $\mathrm{H}$ memperoleh skor 9 dan subjek $M$ memperoleh skor 8. Pada pertemuan ke-11, subjek G mengalami trend peningkatan dari pertemuan sebelumnya dengan skor 10 , selanjutnya pada subjek $\mathrm{H}$ dan $\mathrm{M}$ diperoleh hasil yang stagnan (sama) dengan pertemuan sebelumnya, yakni pada subjek $\mathrm{H}$ memperoleh skor 9 dan subjek $M$ memperoleh skor 8. Pada pertemuan ke-12, ketiga subjek diperoleh hasil yang stagnan (sama) dengan pertemuan sebelumnya, yakni pada subjek G memperoleh skor 10, subjek $\mathrm{H}$ memperoleh skor 9 dan subjek M memperoleh skor 8 .

Hasil intervensi yang dipaparkan melalui grafik di atas menunjukkan bahwa pada subjek $\mathrm{G}, \mathrm{H}$ dan $\mathrm{M}$ terjadi peningkatan kemampuan berhitung (penjumlahan) sebelum diberikan intervensi (baseline A1) dan pasca intervensi setelah adanya perlakuan dengan memberikan intervensi menggunakan media stamp game. Berdasarkan hasil rata-rata perolehan skor dari fase baseline A1 dan pasca intervensi diketahui bahwa peningkatan terbesar ada pada subjek $G$ dan $\mathrm{H}$ dengan peningkatan masing-masing subjek sebesar 8. Pada urutan kedua ada pada subjek $M$ dengan peningkatan sebesar 7. 
Berdasarkan hasil analisa data yang telah dipaparkan, maka dapat disimpulkan bahwa hipotesis yang diajukan dalam penelitian ini dapat diterima, yaitu media stamp game dapat meningkatkan kemampuan berhitung (penjumlahan) pada siswa sekolah dasar yang slow learner. Hal ini ditunjukkan dari skor kemampuan berhitung (penjumlahan) subjek setelah diberikan intervensi melalui media stamp game yakni pada fase pasca intervensi lebih tinggi dari pada skor kemampuan berhitung (penjumlahan) sebelum diberikan intervensi yakni pada fase baseline A1. Peningkatan ini dapat diketahui berdasarkan analisa grafik yang menunjukkan adanya perbedaan pada saat sebelum diberikan intervensi dan sesudah diberikan intervensi.

Pemberian intervensi melalui media stamp game dilakukan selama 6 kali pertemuan, adanya pemberian intervensi mampu meningkatkan kemampuan berhitung (penjumlahan) pada ketiga subjek. Berdasarkan hasil penelitian pada ketiga subjek, subjek $\mathrm{G}$ dan $\mathrm{H}$ mengalami peningkatan terbesar, yaitu dari fase baseline A1 dengan fase pasca intervensi terjadi peningkatan sebesar 8 . Peningkatan terbesar ini dapat terjadi karena pada saat intervensi subjek berupaya untuk bersungguh-sungguh dan memiliki keinginan yang besar untuk berlatih penjumlahan menggunakan media stamp game secara berulang-ulang, sehingga subjek memiliki pemahaman yang baik mengenai berhitung (penjumlahan) yang benar. Menurut Maria Montessori (dalam, Kusumo 2016), anak mampu berkonsentrasi pada kegiatankegiatan yang menarik perhatiannya dan anak suka mengulang-ulang dalam melakukan kegiatan yang menarik perhatiannya. Pernyataan tersebut sesuai dengan kondisi subjek $\mathrm{G}$ dan $\mathrm{H}$ saat intervensi diberikan, dimana subjek $\mathrm{H}$ dan $\mathrm{G}$ tertarik melakukan penjumlahan dengan media stamp game dan berusaha berkonsentrasi saat mengoperasikan media tersebut, meskipun ada saatnya subjek tetap teralihkan konsentrasinya dengan memainkan alat tulisnya dan menceritakan kesehariannya kepada peneliti.

Subjek $M$ ada pada urutan kedua, dimana dari fase baseline A1 dengan fase pasca intervensi terjadi peningkatan sebesar 7. Hal ini dapat terjadi karena subjek $M$ selama intervensi berlangsung konsentrasinya lebih mudah teralihkan, dan mudah lupa saat kembali pada tugasnya, seperti pada saat subjek mengerjakan soal penjumlahan subjek teralihkan melihat mainan di dalam rak, menggunakan alat tulis sebagai mainan dan bercerita tentang kesehariannya. Menurut Paul (2016) slow learner memiliki kesulitan untuk mempertahankan konsentrasi dan perhatian saat mengerjakan tugas. Akibat dari kesulitan yang dialami menjadikan slow learner saat mengerjakan tugas mudah teralihkan pada hal-hal yang menarik perhatian anak, kemudian saat kembali pada tugasnya, anak slow learner kesulitan mengembalikan konsentrasinya.

Pada subjek $G$, diketahui bahwa $G$ mampu mencapai perolehan skor maksimal yakni 10. Hal ini dapat terjadi karena subjek $G$ memiliki skor IQ yang lebih tinggi (77) dari skor IQ subjek H (75) dan M (71), sehingga subjek mampu mencapai skor maksimal selain dari kesungguhan subjek dalam belajar salah satunya juga ditunjang dari potensi kecerdasan yang dimiliki. Menurut Susanto (dalam Ariyanti \& Muslimin, 2015) salah satu faktor yang mempengaruhi kemampuan berhitung, adalah faktor intern. Faktor intern yang mempengaruhi kemampuan berhitung adalah intelegensi pada anak karena intelegensi sangat penting dalam proses belajar mengajar.

Berdasarkan hasil intervensi dari dua jenis soal yang disajikan yakni penjumlahan tanpa menyimpan dan menyimpan, ketiga subjek lebih menguasai pada soal penjumlahan tanpa menyimpan. Hal tersebut diketahui dari ketiga subjek yang mampu mengerjakan soal-soal penjumlahan tanpa menyimpan dengan benar dan 
dalam waktu singkat dibandingkan saat mengerjakan soal penjumlahan dengan menyimpan. Menurut Arnidha (2015) pada siswa SD kelas rendah (I-III) kesalahan mendasar pada operasi hitung penjumlahan adalah siswa tidak menambahkan simpanan pada waktu menjumlahkan, kesalahan tersebut disebabkan karena siswa kurang teliti dalam menyelesaikan soal atau terlupa tidak menambahkan simpanan saat menjumlahkan. Hal yang sama juga terjadi pada ketiga subjek, dimana pada soal penjumlahan dengan menyimpan ketiga subjek lebih sering melakukan kesalahan karena kurang teliti dan terlupa tidak menambahkan simpanan pada saat menjumlahkan.

Selama proses intervensi, peneliti memberikan penguatan yang positif saat subjek telah selesai mengerjakan satu soal dengan benar. Penguatan positif yang diberikan berupa kata pujian yaitu "pintar" , "good", "kamu hebat", dan bersamaan dengan tindakan "tos" dengan subjek. Pemberian pujian didasarkan pada anak slow learner yang memerlukan penguatan positif sebanyak mungkin untuk mendorong anak memiliki kemampuan yang baik pada materi tertentu (Vasudevan, 2017). Menurut pendekatan behaviorisme, pemberian penguatan positif diberikan setiap kali sebuah stimulus khusus dihadirkan setelah sebuah perilaku dan perilaku tersebut meningkat sebagai hasilnya (Ormrod, 2009). Media stamp game merupakan sebuah stimulus, dimana dengan pemberian penguatan positif diharapkan dapat mendorong anak slow learner untuk memunculkan respon berupa kemampuan berhitung (penjumlahan) yang meningkat.

Maria Montessori mengembangkan media pembelajaran yang dirancang untuk melatih keterampilan motorik dan sensoris pada anak (dalam Gutex, 2013). Maria Montessori memperkenalkan metode belajar yang melatih panca indra dan keterampilan motorik anak melalui alat peraga khusus, di lingkungan ramah anak. Ciri utama dalam lingkungan ramah anak adalah tersedia alat peraga yang mengembangkan kecerdasan melalui rangsangan indera-indera. Pada penerapannya, anak slow learner menggunakan media stamp game dengan melibatkan indera penglihatan dalam melihat warna dan angka yang tertera pada stamp angka, indera pendengaran dalam mendengarkan instruksi dari peneliti dan indera peraba dalam menyentuh serta menyusun stamp angka. melalui media stamp game yang melibatkan berbagai indera anak, anak slow learner menjadi lebih mudah dalam memahami konsep penjumlahan. Menurut Paramita (2017) cara belajar yang mudah bagi anak adalah menggunakan material atau media belajar yang dapat dieksplorasi oleh indera anak, hal ini sangat penting karena proses anak dalam memahami sesuatu adalah dengan menggunakan berbagai inderanya.

Media stamp game pada Montessori disusun dengan menggunakan media konkret/objek nyata. Media konkret tersebut dalam psikologi disebut sebagai rangsangan-rangsangan (stimulus-stimulus) (Gutex, 2013), sehingga dalam hal ini media stamp game diasumsikan sebagai stimulus (rangsangan). Pada pelaksanaannya metode Montessori menciptakan lingkungan belajar yang terstruktur dimana terdapat stimulus berupa media belajar berwujud konkret/nyata dengan langkahlangkah yang sederhana dan bertahap (dari yang sederhana ke kompleks), penggunaan media secara berulang berguna untuk menguatkan konsep yang sedang dipelajari, dan adanya penguatan serta feedback, sehingga metode Montessori ini sesuai dengan konsep dari pendekatan behavioristik operant conditioning, dimana sebuah respon akan diperkuat dan mungkin akan terjadi lagi ketika respon tersebut diikuti oleh sebuah stimulus yang menguatkan (Ormrod. 2009). Pada metode Montessori media stamp game juga berlaku konsep operant conditioning, dimana saat terdapat stimulus yang diperkuat berupa media stamp game yang dilakukan secara 
berulang-ulang maka respon yang muncul adalah anak menjadi lebih menguasai keterampilan berhitung (penjumlahan) dibandingkan keterampilan yang dimiliki sebelumnya.

Pada penelitian ini, anak menjadi lebih mudah menguasai keterampilan berhitung (penjumlahan) melalui media stamp game karena sesuai dengan tahap perkem-bangan kognitif ketiga subjek yang berada pada rentang usia (8-10) tahun. Menurut tahap perkembangan kognitif Piaget masuk pada tahap operasional konkret (7-11 tahun), dimana proses berpikir atau tugas mental dapat dikerjakan selama objek masih terlihat. Pada tahap ini anak juga dapat melakukan operasi konkret dan bernalar secara logis sejauh penalaran tersebut dapat diaplikasikan pada contoh-contoh yang spesifik atau konkret (Santrock, 2012). Menurut Nurhayati (dalam Ariyanti \& Muslimin, 2015) untuk anak kelas rendah (I-III) penggunaan alat peraga khususnya untuk pembelajaran tentang angka atau bilangan masih sangat dibutuhkan karena pada tahap ini pemikiran anak masih terkait dan sebatas pada objek nyata. Alat peraga yang digunakan selama proses belajar dapat membantu anak untuk belajar memahami pelajaran yang bersifat abstrak menjadi pelajaran yang konkret atau nyata. Berdasarkan pernyataan tersebut dapat diketahui bahwa meningkatnya kemampuan berhitung (penjumlahan) pada ketiga subjek dapat terjadi karena subjek mampu melakukan proses berpikir dan bernalar tentang berhitung (penjumlahan) yang diaplikasikan pada stamp angka di media stamp game.

Pada saat penelitian tidak semua subjek selalu mengalami peningkatan, terdapat pula subjek yang ditengah penelitian mengalami penurunan. Seperti pada subjek $G$ saat fase pasca intervensi hari ke-10 mengalami penurunan dari pertemuan sebelumnya sehingga memperoleh skor 9. Subjek $\mathrm{H}$ juga demikian, pada fase intervensi hari ke-8 mengalami penurunan dari pertemuan sebelumnya sehingga mem- peroleh skor 8. Penurunan tersebut dapat terjadi karena pertama, subjek lebih mudah teralihkan pada hal lain yang membuat konsentrasi subjek terganggu seperti pada saat mengerjakan soal penjumlahan, subjek teralihkan melihat mainan di dalam rak, menggunakan alat tulis sebagai mainan dan bercerita tentang kesehariannya. Kedua subjek juga mudah lupa menambahkan simpanan saat mengerjakan soal penjumlahan dengan menyimpan. Menurut Aziz, Sugirman \& Prabowo (2015) slow learner memiliki konsentrasi yang rendah, mudah lupa dan beralih perhatian serta mudah bereaksi terhadap rangsangan tanpa adanya pertimbangan terlebih dahulu.

Penelitian ini berhasil menunjukkan adanya perubahan peningkatan kemampuan berhitung (penjumlahan) pada siswa Sekolah Dasar yang slow learner sebelum dan sesudah intervensi menggunakan media stamp game. Oleh sebab itu media stamp game dapat digunakan sebagai salah satu cara untuk meningkatkan kemampuan berhitung (penjumlahan) pada siswa Sekolah Dasar yang slow learner. Ketika anak slow learner memiliki kemampuan berhitung yang baik, maka dampak psikologis bagi anak slow learner adalah anak akan cenderung percaya diri dan tidak muncul perasaan minder terhadap temantemannya. Selain itu anak akan berani bersosialisasi dengan teman-temannya dan tidak menarik diri dari lingkungan sosialnya (Desiningrum, 2016).

Hasil penelitian yang telah dipaparkan sejalan dengan penelitian Mariyah, Aprinastuti, dan Anggadewi tentang pengembangan alat peraga media stamp game. Hasil penelitian menunjukkan bahwa media stamp game dapat membantu anak ADHD dalam berhitung penjumlahan, selain itu media tersebut dapat menarik perhatian anak sehingga anak dapat duduk dengan tenang selama menghitung menggunakan alat peraga (Mariyah, Aprinastuti, \& Anggadewi, 2017). Prasetya juga melakukan penelitian pengembangan alat peraga Montessori media stamp game 
untuk kompetensi penjumlahan dan pengurangan. Hasil penelitian menunjukkan bahwa media stamp game memiliki kualitas yang sangat baik dan efektif untuk meningkatkan minat, konsentrasi dan kemampuan siswa dalam melakukan penjumlahan dan pengurangan (Prasetya, 2015).

Penelitian yang dilakukan ini tidak lepas dari beberapa hambatan yang dialami, yaitu pada pertemuan intervensi keempat media yang digunakan mengalami kerusakan, rentang waktu penelitian yang terbatas, dan subjek yang mendapatkan jadwal intervensi pada siang hari perhatian atau konsentrasinya mudah teralihkan sehingga proses intervensi menjadi kurang efektif dan membutuhkan waktu yang lebih lama. Kepada peneliti selanjutnya agar lebih mematangkan konsep dan waktu pelaksanaan intervensi. Selain itu dalam penelitian ini belum menggunakan kelompok kontrol, sehingga belum ada perbandingan hasil antara kelompok yang diberikan intervensi (kelompok eksperimen) dengan kelompok yang tidak diberikan intervensi (kelompok kontrol). Keterbatasan dalam penelitian ini dapat dijadikan evaluasi dan perbaikan dalam penelitian selanjutnya. Dengan demikian proses intervensi menggunakan media stamp game dapat memberikan hasil yang maksimal.

\section{Simpulan dan Saran}

Berdasarkan hasil penelitian dapat disimpulkan bahwa media stamp game dapat digunakan untuk meningkatkan kemampuan berhitung (penjumlahan) pada siswa Sekolah Dasar yang slow learner. Hal ini ditunjukkan dari skor kemampuan berhitung (penjumlahan) ketiga subjek setelah diberikan intervensi melalui media stamp game yakni pada fase pasca intervensi lebih tinggi dari pada skor kemampuan berhitung (penjumlahan) sebelum diberikan intervensi yakni pada fase baseline A1. Pada fase baseline A1 perolehan skor yang dimiliki ketiga subjek ada pada rentang 1 hingga 2 sedangkan pada fase pasca intervensi, perolehan skor yang dimiliki ketiga subjek ada pada rentang 8 hingga 10.

Saran dari penelitian ini meliputi, bagi guru pendamping khusus disarankan dapat menggunakan media stamp game untuk meningkatkan kemampuan berhitung (penjumlahan) pada siswa Sekolah Dasar yang slow learner karena media stamp game berwujud konkret, sederhana, dapat dilakukan secara berulang-ulang dan memudahkan bagi anak slow learner untuk memahami konsep berhitung (penjumlahan). Bagi orang tua yang memiliki anak dengan slow learner disarankan dapat menerapkan media stamp game untuk membantu anak memberikan pemahaman mengenai berhitung khususnya penjumlahan. Media stamp game memiliki bentuk sederhana sehingga dapat dibuat sendiri oleh orang tua dengan biaya yang murah, selain itu saat pembuatan media stamp game ini disarankan orang tua memilih bahan-bahan yang kuat seperti lebih memilih menggunakan triplek yang tebal dari pada kertas karton, lem kayu dengan perekat yang kuat dan kertas stiker angka agar angka yang ada pada stamp tidak mudah lepas. Media stamp game memiliki cara penggunaan yang sederhana, sehingga orang tua dapat dengan mudah menerapkan kepada anak dan membimbing anak saat belajar. Bagi peneliti selanjutnya disarankan untuk membuat media stamp game dengan bahan yang lebih kuat, sehingga selama proses intervensi media tidak mengalami kerusakan.

\section{Daftar Pustaka}

Abdurrahman, M. (2003). Pendidikan bagi anak berkesulitan belajar. Jakarta: PT. Rineka Cipta.

Adhalia, D. \& Gunanto. (2016). ESPS (erlangga straight point series) matematika untuk SD/MI kelas II. Jakarta: Erlangga.

Arikunto, S. (2007). Dasar-dasar evaluasi pendidikan. Jakarta: Bumi Aksara.

Ariyanti, \& Muslimin, Z. I. (2015) 
Efektivitas alat permainan edukatif (APE) berbasis media dalam meningkatkan kemampuan berhitung pada anak kelas 2 di SDN 2 Wonotirto Bulu Temanggung. Jurnal Psikologi Tabularasa, 10(1), 58-69.

Arnidha, Y. (2015). Analisis kesalahan siswa dalam menyelesaikan soal operasi hitung bilangan cacah. Journal e-DuMath, 1(1), 52-63.

Aziz, A. N, Sugirman, \& Prabowo, A. (2015). Analisis proses pembelajaran matematika pada anak berkebutuhan khusus (ABK) slow learner di kelas inklusif SMP Negeri 7 Salatiga. Jurnal Matematika Kreatif-Inovatif, 6(2), 111-120.

Chauhan, S. (2011). Slow learners: Their psychology and educational programmes. International journal of multidisciplinary research, 1(8), 279289.

Dasaradhi, K., Rajeswari, S. R., \& Badarinath, P. (2016). 30 methods to improve learning capability in slow learners. International Journal of English Language, Literature and Humanities, 4(2), 556-570.

Desiningrum, D. R. (2016). Psikologi anak berkebutuhan khusus. Yogyakarta: Psikosain.

Frengky. (2008). Model pembelajaran matematika siswa kelas satu sekolah dasar. Jurnal Psikologi, 35(2), 151163.

Garnida, D. (2015). Pengantar pendidikan inklusif. Bandung: PT Refika Aditama.

Gutex, G. L. (2013). Metode Montessori. (Terj. Lazuardi. A.L.). Yogyakarta: Pustaka Pelajar.

Irving, S. C. (2017). Montessori parent education: An action research report. Master of Arts in Education Action Research Papers, 208, 1-36.

Kusumo, E. L. (2016). Montessori di rumah. Erlangga: Jakarta.

Latipun. (2015). Psikologi eksperimen. Malang: UMM Press.
Lillard, A. S. (2013). Playful learning and montessori educations. American Journal of Play, 5(2), 157-186.

Malik N., Rehman G., \& Hanif R. (2012). Effect of academic interventions on the developmental skills of slow learners. Pakistan Journal of Psychological Research, 27(1), 135-151.

Mariyah, Aprinastuti, \& Anggadewi. (2017). Pengembangan alat peraga untuk meningkatkan kemampuan belajar matematika pada anak dengan ADHD. Prosiding Temu Ilmiah $X$ Ikatan Psikologi Perkembangan Indonesia dengan Tema Peran Psikologi Perkembangan dalam Penumbuhan Humanitas pada Era Digital, 240-250.

Mumpuniarti, Rudiyati, Sukinah, \& Cahyaningrum. (2014). Kebutuhan belajar siswa lamban belajar (slow learner) di kelas awal Sekolah Dasar Daerah Istimewa Yogyakarta. Jurnal Pendidikan, 1-15.

Mumpuniarti. (2017). Challenges faced by teachers in teaching literacy and numeracy for slow learners. Journal of Sustainable Development, 10, (3), 243-249.

Muppudathi, G. (2014). Role of teachers on helping slow learners to bring out their hidden skills. International journal of scientific research, 3(3), 98-99.

Nataliya, P. (2015). Efektivitas penggunaan media pembelajaran permainan tradisional congklak untuk meningkatkan kemampuan berhitung pada siswa sekolah dasar. Jurnal Ilmiah Psikologi Terapan, 3(2), 343358.

Ormrod, J. E. (2009). Psikologi pendidikan Jilid 1. Jakarta: Erlangga.

Paramita, V. D. (2017). Jatuh hati pada Montessori. Yogyakarta: PT Bentang Pustaka.

Paul, P. B. (2016). Coping with slow learners. International Journal of Management and Applied Sciences, 2(12), 56-58. 
Prasetya, A. E. (2015). Pengembangan alat peraga berbasis metode montessori untuk kompetensi penjumlahan dan pengurangan, 841-846.

Santrock, J. W. (2012). Life-span development: Perkembangan masahidup jilid I. Jakarta: Erlangga.

Santrock, J. W. (2014). Psikologi pendidikan. Jakarta: Salemba Humanika.

Sunanto, J., Takeuchi, K, \& Nakata, H. (2005). Pengantar penelitian dengan subjek tunggal. Center for research on international cooperation in educational development (CRICED) University of Tsukuba, Jepang.

Taylor, R. L. (2009). Assessment of exceptional students: Educational and psychological procedures (8th. ed). United States of America: Pearson Education, Inc.

Tim Bina Karya Guru. (2014) Terampil berhitung matematika untuk SD/MI Kelas II. Jakarta: Erlangga.

Vasudevan, A. (2017). Slow learnerscauses, problems and educational programmes. International Journal of Applied Research, 3(12), 308-313.

Wiropati, Y. (2015). Peningkatan kualitas pembelajaran matematika dengan menggunakan media audio visual bagi anak slow learner di SDN Pajang I Surakarta (Sekolah Inklusi). Jurnal Profesi Pendidik, 2(2), 50-62. 